\title{
Recruitment Model Rediscovered in Thirukkural: Its Relevance in Modern HRM
}

\author{
Dr. Alka Jain \\ Lecturer cum Placement Officer, SUbodh Institute of Management \& Career Studies,Jaipur
}

\begin{abstract}
The study attempts to describe the historical background of recruitment and selection process in ancient Tamilian India. It discusses essential skills managers need in their emergent role as a recruiter.The study starts with understanding recruitment and selection as HR role of a manager.It analyses Thirukkural's theory of recruitment with the help of translation of the verses of chater 51 and 52in Thirukkural. Modern management theories by Gary Dessler, Gareth Roberts are also discussed. Big Five theory is also looked at from Thirukkural point of view. Relevance of verses of Thirukkural is established by seeing their reflection in modern HRM literature.This may prove useful in developing more sophisticated model of recruitment eradicating all flaws being practiced by today's managers. For example commonly used technique of western recruiters- Testing in a real life situation is not suitable according to Kundkundacharya. Such studies may help stopping modern Indian recruiters from following recruitment techniques of western employers blindly.

Keywords: Thirukkural, Recruitment, HRM, Human Resource Development, Selection, Testing, Skill set, expertise, Competencies , Employee, Candidate, Recruiter
\end{abstract}

\section{Research Questions}

1. Does Thirukkural explain the process of recruitment and selection with a special emphasis on Dos and Don't's in the process?

2. Are these Do's and Dont's relevant for today's HR managers and recruiters?

\section{Research Methodology}

Purpose of the research is to analyse an ancient recruitment model and to see if it is relevant for modern recruiters of the economy. This study starts with a thorough reading of 'Thirukkural' with a special focus on chater 51 and 52. The verses were studied from Sanskrit translation of the book. A comparison was made between modern theories of recruitment and "Thirukkural' theory of recruitment rediscovered in the chapters 51 and 52.The research is exploratory in nature.

\section{Thirukkural: An Introduction}

The book is a gem of ancient Jain Tamil literature, it was written by Kundkundacharya. It is divided into 108 chapters which are named 'Pariccheda' in the Sanskrit translation 'Kural kavya' by Govind Raj. The Thirukkural is written in metrical verses of two lines called 'Kural'. These are considered to be sacred verses of Digamber Tamil Jains.

\section{What is Recruitment and Selection?}

Recruitment and Selection is often viewed as the process from inviting applications to up to the decision point on the candidate who has applied for a vacancy in an organization.

According to Elizabeth M Christopher, Larry E Smith, "Usually there are five stages of recruitment : Job Analysis, the recruitment process, selection of candidates, interviews and tests."

\section{Recruitment and Selection Process in Thirukkural}

Kundkundacharya's main purpose seems to be to help recruiters to make decisions on the way they will go about the recruitment process. The principles involved in selection are the same as involved by modern management scholars. His principles of selection are generalized for all types of organizations, whether a large multinational with dedicated HR department, a small enterprise with limited resources. The key issue is to apply these principles successfully in an organization to have the best human resource in the industry. Thirukkural covers various stages of recruitment and selection process.

\section{Kurals on Recruitment and Selection}

Chapter 51 and 52 of Thirukkural throw light on recruitment process of Kundkundacharya's era. The Acharya develops a model of recruitment process. Verse 2 of Chapter 51 gives a clear hint that the author is communicating with the employer or recruiter directly: 


\section{Chapter 51}

Verse 1 : "अर्थो धर्मश्च कामश्च प्राणानां भायामेव च , उपुयक्त परीक्षार्थं चतर्स्तो निकषा मता:] " Meaning "dharma (religion), artha (Money), Kama(to fulfil the desires) and praana bhaya (fear of life) should be tested before selection of an employee in an organization."

Verse 2 : अप्रतिष्ठा भयं यस्य निर्दोष: कुलजस्तथा, स एव पुरुषो योग्यस्त्वसेवार्थं महीपते]

"The one who is born in a reputed family, is above any flaw and is afraid of bad fame, he only is suitable for your selection."

Verse 3 : ज्ञान विज्ञान सम्पन्नो यति कल्पोSपि यो नर:,सो Sविचारे अति तत्वत:]

"When you test you will come to know that knowledgeable people too have areas of which they have nil knowledge."

Verse 4 : नरस्य सद्गुणान् पश्य दोषानपि तथैव च,अथिका: संति ये तेषु प्रकृतिस्तस्य ताहशी]

"Have a look at a person's good qualities and virtues and then see his weaknesses or bad qualities also,whichever is greater in number, that decides the type of inner nature of a person.” This means Test the inner nature of an applicant by quantitative technique of evaluating a candidate's good and bad qualities.

Verse 5 : वर्तते किमसौ क्षुद्र:किंन्नु वायमुदारथी,आईटीआई वेत्तुं नर: पश्येदाचारं निकषोपमं]

"Do you want to judge whether this person is broadminded or a narrow minded one? Remember that your behavior decides what type of character is yours?"

Verse 6 : असमीक्ष्य न कर्तव्यो विश्वासो निष्कुटुम्बिन:, एकाकिनो यतस्तस्य मोह लज्जा विहीनिता]

"Be alert! Be careful while selecting those who do not have a family or relatives because they may not understand the meaning of good relations and may lack affection in their treatment."

Verse 7 : मूढ कार्यविधे: शून्यं य: करोति स्वमंत्रदम्,केवलं प्रीतिमात्रेण स नृपो विपदां पदम]

"If you wish to recruit someone as your loyal bodyguard just because you like or love him, then be assured that he will surely land you in great trouble some day."

Verse 8 : अपरीक्षित विश्वासं कुरुते यो हि मानव:संसंतति कृते दुःखबीजानि वपति ध्रुव]

"One should not trust someone without testing and examining his loyalties because such an act will bring troubles to you for generations."

Verse 9 : परीक्षितस्य विश्वास: कर्तव्यो हृष्ट चेतसा परीक्षिताय तद्योग्यं कार्यं देवं नृपालकै:]

Do not trust any one without proper testing,After appropriate tests assign jobs suiting his qualifications and skills."

Verse 10 : अज्ञात कुल शीलस्य विश्वासो भय दायक:एवं विज्ञात शीलस्याप्रत्ययो दुःख कारक:]

"Trusting someone whose 'kula' is not known to you and not trusting someone whose 'kula' is known to youboth these things will bring troubles to you."

Chapter 52

Verse 1: सदसच्चोभयं वेत्ति परमश्रयते शुभम्,एवं यस्य मनोवृत्तिर्नियोक्तव्य: स कर्मसु

"For a vacancy select only the one who understands good and bad qualities, both, but follows good only in life."

Verse 2: शासर्नागेषु विस्फ़र्तिर्यस्यास्ति प्रतिभाबलात्,यो हत्त्ता च विपत्तीनां स कार्य: कार्यवाहक:]

"While recruiting a manager for your state, select the one who can increase the assets of the state and keeps it safe from all troubles."

Verse 3 : दयावान बुद्धि संपन्न: कार्येषु द्रुत निश्चय:, यो लोभेन विनिर्मुक्तःस कार्यो राज्यसेवक:]

While selecting an employee, make sure that he is merciful to others, has adequate intelligence for the job, is fast in decision making and are above all greeds."

Verse 4 : ईदशोडपि जना: संति येषाम् सर्वत्र पौरुषम्, परम ते पि विलोकयंतेकाले कर्त्तव्य विच्युता:]

"There are people who pass all tests but fail in real life situations."

It seems that the message of this verse has forced Gary Dessler to write in his book on Hman Resource Management " The conditions under which the person takes the test resemble the work situation ." This statement approves the relevance of recruitment techniques in the eyes modern management scholars also. Gary Dessler gives a supporting statement further in his book when he writes, "In order for a selection test to be useful, a recruiter should be fairly sure test scores relate in a predictable way to performance on the job."

Verse 5 : कार्येषु पूर्णदाक्षिण्यं शक्तिं शान्तिविधायिनीम्,इति वीक्ष्यैव दातव्यं कार्यं न प्रीती मात्रतः

"Don't recruit someone just because you love or like him, in stead judge him by his competencies, skill set and calm implementation of planning while accomplishing a task in hand." 
Verse 6 : मानवं योग्यतां वीक्ष्य योग्य कर्मणि योजयेत्, योग्य काले च संप्राप्ते कार्यारंभ च कारयेत]

"First see the expertise of a person, then assign jobs accordingly.Wait for the right time and ask him to start the task when appropriate time comes."

Elizabeth M Christopher and Lary E Smith echo the same message in their book when they say, "Be alert to spot new levels of expertise that will be required in the organization, for example to market, install and maintain new products and services." If we remove new, then the whole message seems to be a replica of the message of this verse.

Verse 7: शक्तिं कार्यं च वीक्षेत पूर्व भृत्यस्य भूमिप:, पश्चात्कार्यं तदायत्तं विदध्याद्गत संशय:]

"Analyse the stamina/expertise of the employee and the (skill set required for) task to be assigned, only after that assign the task to him."

Verse 8 : तत्पदायोपयुक्तो यं यद्येवं निश्चितं त्वया तस्यानुरूप शोभापि तर्हि त्वय्यवशिष्यते]

"When you finally decide that this particular person is appropriate for this particular designation, then designate him for the same."

Verse 9 : भक्ते दक्षे च यो भृत्ये रुष्टो भवति भूपति:, नूनं तस्य भवेदेव भाग्यश्री परिवर्तितः]

"The person who gets angry on his loyal and skilled employees, the Goddess Lakshmi will turn her face away from him."

Verse 10 : प्रत्यहं प्रत्यवेक्षेत भृत्य कार्याणि भू प्रभु:,भृत्या यत्र विशुद्धा हि तद्राज्यम् न विपद्यते]

"The king should monitor the jobs done by his employees on daily basis, because the state can never land in trouble whose employees are pure(hard working)."

\section{Dos and Donts in Recruitment Model of Thirukkural}

Do's - What is to be done in the process of recruitment

1. Four criteria of selection : Dharma, Artha, Kaama, Fear of life are to be taken into account while making final selection of employees. Thirukkural explains the non materialistic approach of recruitment, while modern management theories are based on materialism, Jainism covers all the four aspects of life in business management problems.

2. Background check : The techniques used by kings addressed in Thirukkural might have been slightly different - say in place of family background check, with increasing population and globalised economy modern recruiters have shifted to reference check. For example Gary Dessler says, "Even though most people prefer not to give bad references, most companies still carry out some sort of reference check on their candidates." Though western recruiters do not follow this approach but in India trusting someone after checking his family background is too common. There are organizations where employees of the same religion as its owner/CEO are found. It is a common practice in minority communities. Jain organizations prefer Jains, Brahmins prefer Brahmins and Muslims prefer muslims in many cases.

3. Knowledgeable also experience lack of knowledge in some areas : We come acrosee situations in life when highly qualified people who have learnt everything theoretically fail in real life situation. Difference between theory and practical life situations is depicted well in Thirukkural and the recruiter is advised to take people who are good in real situations too.

4. Character/inner nature of a candidate should be checked : Inner nature of a candidate is very important for an organization, as it decides the core path of implementation of strategies and policies designed by higher managements to achieve the organizational goal.In modern world also it has great importance.

5. Enough alertness is required when trusting people not having a family : This is clear psychological intonation of family background check. The author indicates the psychological status of the people who do not have a family to which they belong. Such an employee may lack required amount of affection and tolerance as per Kundkundacharya.

6. Selection of skilled candidate : Candidates with appropriate skill set should be selected in the end of recruitment process.skills are the first and foremost criteria of selection as per Thirukkural model of recruitment and selection.

7. After testing an employee a job suiting his/her skills should be assigned : Thirukkural advocates relevant skills for a particular job. After testing the candidate, whether he is suitable or not for the job vacancy, the duties should be assigned. An engineer should not be taken as medical advisor.

8. Evaluate good and bad qualities of an applicant : Thirukkural accepts that we all have a blend of good and bad qualities. A recruiter is supposed to analyse these qualities and understand the basic inner nature of an employee. Then the decision should be taken whether he will be able to act as a suitable employee.

9. Select an employee who can be an asset to the company: This is common statement used by modern recruiters "This employee can be an asset for the company" while recommending a candidate for selelction 
to higher authorities. This has been said in thirukkural long ago that onlt The one who can add to the organisation's resources is to be selected.

10. Passionate, wise and prompt decision maker should be selected : Emotional stability and stamina is also to be checked while selecting a candidate after testing and interviews.

11. Physical Examination: Balance between an employees stamina and the task assigned should be maintained by the recruiter.Gary Dessler uses the same idea in his book saying, "One is to verify that the applicant meets the physical requirements of the position ;another is to discover any medical limitation that you should take into account in placing the applicant" Surprising similarity of ideas in a hundred years old book and a twenty first century book. Thirukkural advocates the idea that no test is foolproof.

12. Designation suiting the qualification of an employee : Thirukkural stresses that qualification of a candidate and designation given to him should be in line. A ph D degree holder should not be assigned the designation of a clerk. This theory is applied by modern recruiters also.

13. Monitoring the task of all the employees : Western managers end the recruitment process after selection and induction (at the most), but the recruitment model of 'Thirukkural is more advanced in that sense. As last verse of the chapter 52 talks about continuous monitoring of the employees by the top management through various tools and techniques.In this manner Thirukkural recruitment model ends at controlling.

\section{Don'ts - What is not to be done in the process of recruitment}

1. Do not select unwise candidates : The author advises recruiters not to select unwise candidates . This refers to general awareness and knowledge of current affairs assessed in face to face interviews or written test techniques of testing. If a candidate lacks general intelligence or is not presentable enough, then he should be rejected initially only, should not be sent for further tests. This initial elimination reduces the cost of recruitment process.

2. Do not trust an applicant before testing him/her: An employee should be selected only after appropriate testing, not before that. If an employee is taken withouttesting, then the chances of his failure in the work field are higher.

3. Do not select a person with bad inner nature: If quantitative technique of assessing qualitative aspect of a person in terms of his good virtues and bad qualities results in a negative impression of the candidate, then he should not be selected.

4. Do not select your favourites : A recruiter is advised not to select his favourites on roll, but to take those who are suitable for the job with an appropriate skill set and qualification for the vacancy.

5. Do not disrespect hard working and dedicated employees : Thirukkural advises the employer to respect and recognize the hard work and dedication of employees. Infact it says that it should not be ignored in any case or the organization may loose all profitable gains.

6. Do not trust strangers/new employees : When a new employee is selects and taken in a department, the boss should not start trusting him at once. Both need time, the new employee to get absorbed in the culture and the boss getting used to new employee's style of working.

7. Do not doubt trusted employees : Again an advice is given to employer that they should not doubt an employee once he proves himself in the organisation. Because doubting a trustworthy person is a negative HR policy that may bring the morale of the employees down.

8. Do not rely on test scores too much : Only passing all the tests is not enough, real life sense of responsibilities is also to be considered. This shows that significant relationship between scores on the test and performance on job may be missing. Though modern management scholars like Gary Dessler have developed an expectancy chart based on test score and performance on job relationship, but we experience in real life that such relationship may be missing in many cases. For example an actor doing well in rehearsals may face camera fear in real shot taking process of a a scene.

\section{Modern Theories of Recruitment and Selection}

1. Gareth Roberts gives a four point selection model in his book. According to him , "The key attributes of effective selection are :

- A clear and precise specification : of required skill set and duties and responsibilities of a would be employee.

- Effective use of multiple techniques : This talks about proper use of all testing techniques while selecting a person.

- Elimination of redundant processes : Unneccessary rounds should be eliminated in the process of selection.

- Evaluation and continuous improvement : Monitoring all the employees for evaluation of their performance and motivate them for further improvement is important for organizations. 
This theory is in line with Thirukkural Recruitment Model as all the four points are reflected as it is in Dos and Donts analysis of this ancient model.

2. The Big Five(page 207 Gary Dessler) - Industrial psychologists often emphasize the 'Big Five' dimensions as they apply to personnel testing :

- Extraversion,

- Emotional Stability/Neuroticism,

- Agreeableness,

- Conscientiousness

- Openness to experience

The above big five competencies of an employee are discussed thoroughly in Thirukkural Recruitment Model. According to Gary Dessler, "Employers should use personality test cautiously, particularly if the focus is on aberrant behavior."He lists three selection tools :

- Polygraph

- Honesty Tests (Paper and pencil honesty tests have been used with success )

- Graphology

Thirukkural theory does not list modern techniques of testing like The in Basket, Leadership Group Discussion, Management games, Individual presentations, objective tests and the interviews, but it surely talks about the result of these testing techniques.

\section{Contribution}

If the recruitment and selection model of 'Thirukkural' provides an overview to the recruiters which enables them to map their process against this ancient one.

If this recruitment strategy fits into the wider HR strategy, then the model is supposed to be a successful one in modern business world too.

Thirukkural looks at how to gauge whether the person applying is the right person for the job. A wide range of tools and techniques is available in the book. Advantages and disadvantages of each tool can be discussed.

'Thirukkural Recruitment and Selection Model' ensures that the process is right starting with effective decision making, the need for checks and safeguards, consideration of equal opportunities, the importance of settling the new person into the role and the process of measuring the effectiveness of the recruitment itself.

\section{Limitations}

The recruitment process is an ancient one and does not include women when it talks of 'bhritya' (employees). When we generalize this model and would implement it in modern organizations HRD programmes, women are to be included as they constitute more than $40 \%$ of manpower in Indian economy.The book was written in an era when women were supposed to work at home only, not in organizations.

These verses are meant for a king who was the authority of all selections made in his state.Hence depict a centralized recruitment system. While generalizing this centralized system for modern recruiters, the author assumes that the king plays the role of a recruiter/ employer.

\section{Contribution}

Getting benefitted from the knowledge of our ancestors has always enriched the skills of mankind. By understanding basic qualities of an employee it may be easier for the recruiter to get quality people by assessing them on the basis of recruitment model of Thirukkural as it is based on simple psychological and social effects on work performance.

Chapter 51 and 52 of 'Thirukkural' provide an advice on how to recruit and select people for a job or designation. Such models are more helpful in modern business world as HR department's responsibilities have gradually become broader and more strategic since the days when business people began including 'personnel departments' in their organization charts.

The 'Thirukkural' written hundreds of years ago, enlightens us on recruitment and selection techniques leading us towards an economy with organizations of competent staff. The Thirukkural tackles the issues of recruitment and selection from the grass roots level of recruitment needs based on human psychology, such an approach surely enhances the quality of recruited staff. 


\section{References}

[1]. Abhishek Roy Caudhary, 'Why Employees Get Demotivated?" HRM Review,Oct- Dec 2011, The Icfai University Press, Hyderabad.pp46-49.

[2]. Gareth Roberts, 'Recruitment and Selection' Jaico Publishing House, Mumbai,2008.

[3]. Elizabeth M Christopher, Larry E Smith, 'Managing Recruitment Training and Development' Viva Books Pvt. Ltd, 2009

[4]. Gary Dessler, 'Human Resource Management', Pearson Education Inc., New Delhi, 2006

[5]. Ka Naa Subramanyam, ' Thiruvalluvar and His Thirukkural' Bhartiya Jnanpeeth, New Delhi, 1987.

[6]. Dr. Inderraj Baid, 'Jain Tamil Sahitya aur Thirukkural' Samyaggyan Pracharak Mandal, Jaipur,1987.

[7]. Govind Rai Jain Shastri, 'Kural Kavya', Vitrag Wani Trust Registered,TikamGarh, M.P.,2001.

[8]. P. S. Sundaram, 'The Kural. Penguin Books: London, 1990.

[9]. Richa Sharma, A H Ansari, Kanika T Bahl, 'Innovative Human re source Management:The Need of the Hour', HRM Review,March 2010, The Icfai University Press, Hyderabad.pp25-29 